\title{
Traditional Ecological Knowledge and Contemporary Changes in the Agro- pastoral System of Upper Spiti Landscape, Indian Trans-Himalayas
}

\author{
Rashmi Singh $^{1 *}$ D, Rishi Kumar Sharma², Suresh Babu ${ }^{1}$ and Yash Veer Bhatnagar ${ }^{3}$
}

\begin{abstract}
Pastoral systems are known to be prone to social, political and ecological uncertainties. Traditional ecological knowledge that the pastoral communities hold around their bio-physical environment has been a key to cope with stressors and adapt to the rapid socio-economic changes. We examined traditional ecological knowledge (TEK) on livestock and resource management, factors influencing livestock production and concurrent changes in an agropastoral system. We used mixed methods by conducting 44 semi-structured interviews, 10 key informants' interviews and resource mapping in five villages of Upper Spiti Landscape, western Himalaya. Our specific objectives were to (i) document TEK on livestock diet and management and (ii) understand the drivers and consequences of the change in the agro-pastoral society and associated traditional knowledge system. The herders of the study area possessed extensive knowledge of livestock diet and fodder species preference. They used this knowledge to optimize livestock grazing in pastures during summers and to fulfil the nutrient requirements of livestock species during stall feeding in winters. Seasonally, the aspect, altitude and accessibility of the pasture influenced the rotational use of pastures. In contrast, the quality of forage and water availability, distance of the pasture from village and threats from predators influenced the selection of grazing areas daily. There are evident changes in the livestock production system and signs that TEK is eroding in the region. Primary contributing factors to loss of TEK include changing aspirations of local people. These aspirations were related to employment in lucrative alternative options like cash crops and tourism, out-migration of the young generation for higher education and the arrival of immigrant labourers as new actors in livestock management. Livestock numbers in the study site remained dynamic between the year 2003-2016 owing to the substantive social and ecological changes. Our results suggest that while the traditional knowledge persists, the signs of erosion in traditional knowledge and associated changes in current herding practices are evident. We argue that recent changes in the pastoral social-ecological system, especially loss of TEK and non-traditional rearing practices, due to increasing dependence on immigrant labourers, may have negative implications for livestock production, rangeland health and wildlife conservation goals in the long run. Long term site-specific studies on livestock production and associated knowledge would be critical for adaptive rangeland management and policies.
\end{abstract}

Keywords: Pastoralism, Trans-Himalaya, Traditional ecological knowledge, Livestock production, Spiti, Socio-economic changes, Immigrant labourers

\footnotetext{
* Correspondence: rashmi89singh@gmail.com

'School of Human Ecology, Ambedkar University Delhi, New Delhi 110006, India

Full list of author information is available at the end of the article
} 


\section{Introduction}

Traditional pastoral and agro-pastoral societies inhabit the rangelands across Central, South-West and South Asia and Africa (Goldstein and Beall 1990). Local pastoral communities in these regions have evolved and maintained livestock production as an adaptation to the local geoclimatic conditions. They have been adapting well to the social, political and ecological stochasticity in the pastoral social-ecological systems by using their traditional institutional management and traditional ecological knowledge (TEK) (Mortimore and Turner 2005; Mortimore 1998; Scoones 1994; Behnke et al. 2011; Li and Li 2012; Reid, Fernández-Giménez, and Galvin 2014; Ahmed and Ahmed 2019). However, the role of pastoral livelihoods and their impacts on rangeland health is a highly debated subject in high-altitude rangelands of India, Tibet, Inner Mongolia and parts of China (Ho 2000; Harris 2010; Singh et al. 2013; Mishra 2001; Mishra et al. 2004; Jun Li, Ali, and Zhang 2007; Bagchi and Ritchie 2010b; Thapa, All, and Yadav 2016; Kakinuma et al. 2013; Wang and Wesche 2016). The studies mentioned above highlight overuse and degradation by the pastoral communities following the widely cited theory of 'tragedy of the commons' (Hardin 2009). Rangelands being a common property resource are considered to be overused by the pastoral communities, which keep large herds of livestock, resulting in rangeland degradation (Dregne, Kassa, and Rosanov 1991; Beinart 1996; Mishra, Prins, and Wieren 2001). Critiques of this view, on the other hand, point to a well-adapted resource management system of the pastoral communities, wherein communities sustainably manage their livestock and natural resources by using TEK and local institutions (Scoones 1994; Bilal Butt 2011; Jun Li, Ali, and Zhang 2007; Ostrom 1990; Adriansen 2008; Bhasin 2012; Mapinduzi et al. 2003; Fernandez-Gimenez 2000).

Loss of TEK is an emerging global issue, with only a few regions continuing to preserve and manage the natural resources by using traditional knowledge (GómezBaggethun and Reyes-García 2013). TEK includes factual knowledge embedded in the local cultural values as well as ethics for sustainable natural resource use and management by the local institutions of indigenous peasant and pastoral communities (Davis 2005; Berkes 2008, 2004). TEK possessed by the communities may help in understanding the influence of climatic and social changes on the environmental management practices at a local scale (Nakashima 1991; Ferguson, Williamson, and Messier 1998; Mallory et al. 2003; Paltsyn, Gibbs, and Mountrakis 2019; McMillen, Ticktin, and Hannah 2017; Wyllie de Echeverria and Thornton 2019; Fernandez-Gimenez 2000; Soma and Schlecht 2018). The TEK, therefore, could be of immense value in planning and formulating useful management plans and policies (Berkes and Folke 1998; Turner, Ignace, and Ignace
2000; Berkes 2008). Pastoral social-ecological systems (SES) adapt to the ever-changing social, political and ecological environments, despite being prone to stressors from socio-economic and ecological dimensions (Galvin 2009). These coupled social-ecological systems have complex feedback loops and any disturbance in one of the two components, social or ecological, may significantly influence the other. Understanding TEK, the role of local institutions in governing natural resources and the factors contributing to change in the pastoral socialecological system can be of crucial importance for maintaining the resilience of these systems (Gunderson and Holling 2002; Chapin et al. 2009; Gómez-Baggethun, Corbera, and Reyes-García 2013).

In the high-altitude pastoral communities of South Asia, there are ongoing socio-economic changes driven by access to education and changing aspirations of the young generation, the emigration of the younger generation to cities, labour immigration, cash crop cultivation and an influx of tourism. These are all key factors that negatively influence the pastoral livelihoods and knowledge systems (Johnson et al. 2006; Namgail et al. 2007; Singh et al. 2013; Namgay et al. 2013, 2014; Bhasin 2011; Yamaguchi 2011; Aryal, Cockfield, and Maraseni 2018). Recent studies in Indian western Himalaya point out that the pastoral communities may no longer be practising traditional resource management systems, resulting in an intensification of resource use, characterized by an increasing dependence on immigrants used by local herders for livestock management (Singh et al. 2013; Ghoshal 2017).

Upper Spiti Valley in the Indian State of Himachal Pradesh is a cold desert region inhabited by a traditional agro-pastoral community. The region has gone through rapid socio-economic changes in the last three decades, owing to better road connectivity, access to markets, improved literacy and the advent of a cash crop in the form of green pea (Mishra 2000; Singh, Sharma \& Babu, 2015). Agricultural policy changes at the national and regional government departments that focused on the cultivation of cash crops transformed the self-sustained economy into a market-driven one (Mishra, Prins, and Wieren 2003; Singh, Sharma \& Babu, 2015).

Livestock numbers and species composition have remained dynamic in the region in response to natural, cultural and economic needs in the last few decades. Following the aim of maximizing livestock numbers, goat and sheep numbers increased by $57 \%$ and yak numbers increased threefold between the 1980s and late 1990s (Mishra 2000). In the years between 2003 and 2011, livestock numbers declined by half, and the composition of livestock herds too changed with a sharp decline in sheep and goat numbers (Singh, Sharma, and Babu 2015). Improved income from the cash crop; shortage of human resources for livestock management; the 
emergence of tourism as a lucrative livelihood option; livestock depredation by free-ranging dogs, and extreme climatic events resulting in a shortage of grass in the pastures, drove the decline in livestock numbers and change in composition (Singh 2013; Singh, Sharma, and Babu 2015). Historically, the availability of natural fodder from the pastures for winter stall feeding has been the most critical bottleneck in determining the herd size, since livestock is stall-fed for almost half a year in the winters when snow covers the grazing pastures. The TEK of the herders of Spiti regarding the important fodder species and their availability across the seasons played an important role in ensuring access to the winter stall feel for livestock.

Earlier studies in the region have documented the social and political changes in the pastoral landscapes, their influence on the livestock management and its ecological consequences (Mishra 2000; Mishra, Prins, and Wieren 2003; Singh, Sharma, and Babu 2015; Ghoshal 2017). Nevertheless, the TEK of the pastoral community and the role of this knowledge and local institutions in livestock management remain unexplored. Our study aims to understand the role of traditional ecological knowledge in livestock management and resource use and contemporary influence of socio-economic and demographic changes on the knowledge system. Our specific objectives are to (i) document traditional ecological knowledge on livestock production and pasture management and (ii) understand the drivers and consequences of the change on the agro-pastoral society and associated traditional knowledge system. We discuss the implications of these changes for the pastoral community, rangeland health and wildlife conservation in the landscape.

\section{Study site}

Spiti Valley $\left(31^{\circ} 35^{\prime}\right.$ to $33^{\circ} 0^{\prime} \mathrm{N} ; 77^{\circ} 37^{\prime}$ to $\left.78^{\circ} 35^{\prime} \mathrm{E}\right)$ is in the western Trans-Himalaya, and the entire area is above $3000 \mathrm{~m}$ above mean sea level. Temperatures in winters drop below $-40^{\circ} \mathrm{C}$. Being cold and arid, the vegetation of the area is characterized as dry alpine steppe with almost no trees. Administratively, Spiti lies in Lahaul and Spiti District of the Indian state of Himachal Pradesh. Two thirds of land in Spiti is under the control of the State's Forest Department, and the rest is with the Revenue Department. The entire region is a Wildlife Division and classed as the Cold Desert Biosphere Reserve (c. $7000 \mathrm{~km}^{2}$ ) and has three protected areas-the Pin Valley National Park $\left(675 \mathrm{~km}^{2}\right)$, Kibber Wildlife Sanctuary $\left(1200 \mathrm{~km}^{2}\right)$ and the Chandratal Wildlife Sanctuary $\left(38 \mathrm{~km}^{2}\right)$. The region has high conservation importance, being host to a unique assemblage of high-altitude wildlife species like bharal, Psedois nayaur; ibex, Capra sibirica; Himalayan wolf, Canis lupus chanco; and snow leopard, Panthera uncia. An active conservation programme in the region led by the state agencies and non-governmental organizations aims to reconcile livestock production with wildlife conservation.

People are mainly Buddhist agro-pastoralists, and they have de facto and de jure community rights over land and pastures and lease pastures to migratory herders coming from the neighbouring regions and states (Anon 2011). They belong to three castes, Chechang or the landlords, Dzo or the drummers and Beta or the pipers (Mishra, Prins, Wieren 2001; Singh, Sharma and Babu 2015). All the households rear livestock which includes goats, sheep, yaks, cows, dzo and dzomo (crossbred of yak and cow), horses and donkeys.

We carried out this study in five villages of Kibber Village council locally known as Panchayat that include Kibber (4200 m), Kee (3760 m), Chicham (4120 m), Gete $(4360 \mathrm{~m})$ and Tashigang $(4380 \mathrm{~m})$. Principal crops are Green pea Pisum sativum, black pea (Pisum sativum, a local pea variety) and barley Hordeum vulgare. Apart from these crops, potatoes Solanum tuberosum and apples Malus domestica Borkh are grown in the low elevation areas of Spiti Valley with climate-induced warming resulting in a gradual altitudinal shift of these crops to high elevation parts of the landscape. Cultivation of green pea as a cash crop is a relatively recent trend, which now dominates agriculture (Mishra, Prins, and Wieren 2003; Anon 2011).

\section{Methods}

We collected primary data at two-time durations, first between June 2012 and March 2013 and, second, between October and November 2016. In the five villages of the study area, all the households are agro-pastoralists. We used mixed methods and conducted semi-structured interviews $(n=44)$, key informant interviews $(n=10)$ and resource mapping for understanding pastures' use with the key respondents. We conducted 44 semi-structured interviews representing $15 \%$ of the total households in the study site. Respondents represent herders from all the caste sections (Chechang, Dzo and Beta) and distinct groups based on age. We conducted the first set of interviews to understand livestock management, pasture sharing and changes in the agro-pastoral system. Questions included information about the livestock species, diet specificity of livestock types, forage composition of stall feed and other important considerations that influence the stall feeding. We asked respondents about their perception of change in livestock management and the factors that contribute to this change.

While all the respondents were keen on sharing their knowledge during the interviews, respondents identified as key respondents were only those with at least 15 years of herding experience, an understanding of local names 
and identification of the fodder species in the pastures, knowledge of pasture use and pasture sharing, and their importance for different livestock species. The key respondents also offered a profound reflection on the changes in the agro-pastoral system and the contributing factors. In the second round of data collection in 2016, we conducted in-depth interviews with the selected key respondents $(n=10)$.

For the analysis of fodder species requirements, after a pilot survey, we prepared a list of the local and the scientific names of the plant species with the help of local herders and a trained plant taxonomist. We developed a list of fodder species for every livestock type. We then ranked the importance of each fodder species by summing the number of respondents $(n=10)$ who described the species as necessary for a particular livestock type. For cross-checking of the data, we visited pastures frequently with the herders to confirm the local names of the important fodder species listed (Table 1). For pasture-sharingrelated data, we prepared resource maps on A3-size printed sheets of Google Earth images to understand the resource use and pasture sharing between the villages. Resource mapping exercise was done with the key respondents. Along with the names of pastures and the village they belonged to, collected data included the livestock species that used the pastures, other villages that used them, seasonal patterns of use, quality of pasture as defined by the respondents, aspect and altitude. We later transferred all the spatial data to Google Earth and ArcGIS Geographic Information System.

We analysed all the qualitative data collected from the interviews using content analysis with an open coding process (Denizen and Lincoln 2017; LeCompte and Schensul 1999). We made a master list containing the recurring themes which addressed original research objectives. We collated data under separate thematic headings to understand the patterns concerning the study questions.

\section{Results}

Livestock species in villages of Spiti can be categorized into three groups; small-bodied livestock (goat and sheep); large-bodied (cow and dzomo) and free-rangers (yak and horses). Because of heavy snowfall in the winters, livestock is mostly stall-fed in winter. During summer, all the livestock species, other than free-ranging yak and horses, are taken to forage in the pastures and brought back to night-time corrals for ease of management. In the sections that follow, we present the herders' TEK of fodder species requirements of different livestock species and specificities of their winter stall feed. Traditionally, forage is collected from the pastures during early autumn, for winter stall feed. We then explain the mechanism of pasture sharing and the factors that influence the sharing of pastures between villages of the study area. In the next section, we dwell upon how the changes in the agro-pastoral system, mainly the changes in cultivation practices and policies of the Animal Husbandry department, influenced the livestock numbers, which have historically been dynamic. In the last section we discuss how ongoing demographic and socioeconomic changes have impacted the traditional ecological knowledge in the study area.

\section{Herders' understanding of livestock diet}

Livestock is herded communally over the summers in the study area villages. Herders were well aware of the individual forage species preference of different livestock species under different conditions. Herders reported that free-ranging animals like yak and horses preferred to graze at relatively high altitudes $(4200-5100 \mathrm{~m})$, followed by goat and sheep that favoured slightly lower altitudes (3600-4600 m). Donkeys and cattle preferred the lowest elevation among all the species and were, therefore, grazed close to villages $(<4300 \mathrm{~m})$. In addition to their knowledge of the altitude preference, herders also reported the food resource management strategy of the animals, as reflected in the following response:

Wild herbivore, as well as our livestock, start saving food for future use just before the onset of winters. They would only eat the tips of the forage but not the stems or base. When it snows, they can see the shoot and using their hoofs they scrape away the snow and eat the plant. Donkeys like to eat the root of Keechu (Astragalus rhizanthus) using the same technique.

According to the local herders' knowledge of livestock diet, graminoids and herbs were most important for all the livestock species, with shrubs being marginally relevant. Herders identified 43 fodder species which they perceive to be essential for livestock species. Out of these, 19 fodder species appeared to be most relevant to the local herders and emerged in most of the responses (Table 1). The remaining 24 fodder species were only referred once or twice during the entire period of data collection.

Graminoids were reported to be the most important for yaks, cattle, and horses. In contrast, a mix of graminoids and forb species such as Cousinia thomsonii, Stipa orientalis, Eurotia ceratoids, Carex infuscata and Scorzonera spp. were reported to be essential for sheep and goats (Table 1). Being herded together or at a similar altitude, the diet of goats and sheep showed a lot of similarities. Festuca spp., Carex infuscate and Eurotica ceratoids were 


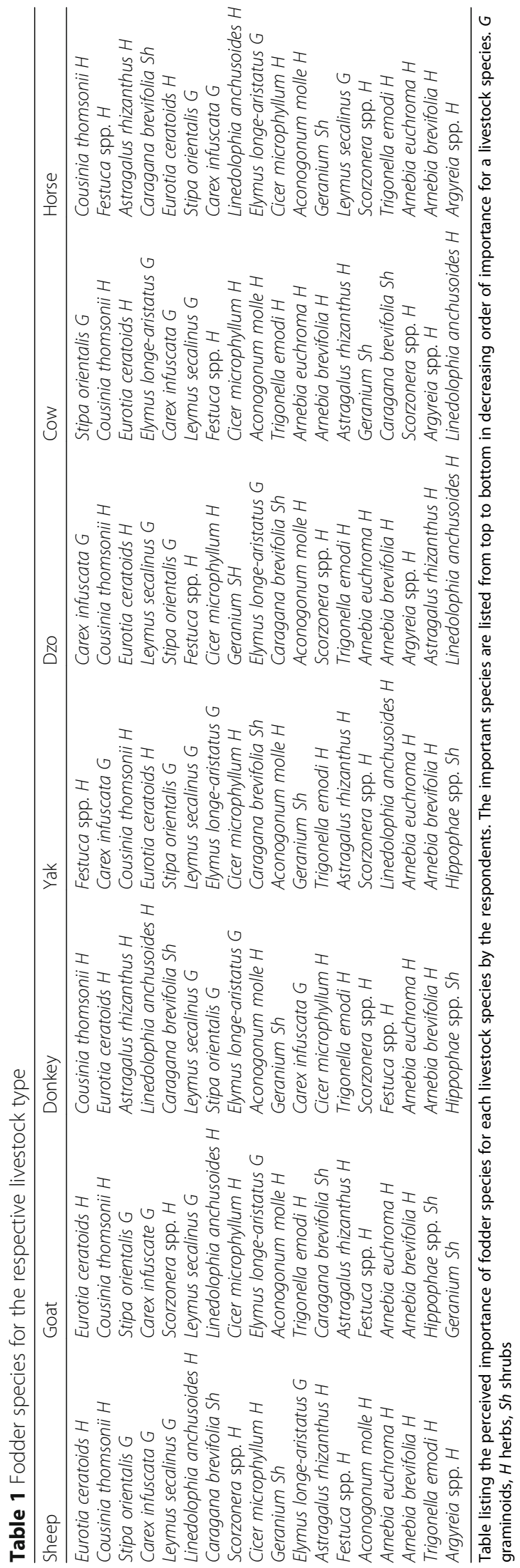


mentioned to be the most crucial fodder species for yak. Fodder species like Leymus secalinus, Elymus longearistatuss, Geranium, Cicer microphyllum and Aconogonum molle did not appear among the top choice for any livestock species. However, they were reported to be consumed by all livestock species and therefore considered important for all the livestock species.

Winter marks a lean period in Spiti. Yaks, which are mainly free-ranging, are brought back to the villages from about late November to mid-April when the pastures are snow-covered. During this period, they are stall-fed three times a day. Cows, horses and donkeys are also stall-fed during winters (November to March), and while goats and sheep graze in pastures near villages in winter, they too are stall-fed twice during winters (November to March) to supplement scarce forage in the nearby pastures.

During winters, crop residues from the green pea plays a significant role in the diet of livestock. One third of every livestock feed comprises green pea crop residue, with the rest being barley fodder and grass species collected from pastures. For cows, 30\% of stall feed contains the weeds and other fodder species collected in and around agricultural fields. Stall feed for yaks comprises $30 \%$ of fodder species collected from the pastures while the remaining $70 \%$ consists of barley residue, grains and hay. Horses are fed wheat and barley, where wheat is a recent replacement for black pea. Goats and sheep are also fed powdered roasted barley locally known as tsampa. Sub-adult yak and demo (female yak) are given a mixture of tsampa and solid remains of the barley brew chang.

The economic status of the family and age of the household's livestock caretaker influenced the stall-feed composition. During the focused group discussion, respondents mentioned that the wealthier families could afford to provide wheat and barley to even their sheep and goats, whereas people who did not have agricultural land and therefore relatively less income, fed their livestock forage collected from the pastures. We found that the household having older family members, above 50 years in age $(n=7)$, usually took better care of the stall feeding for livestock. They prepared different forage mixtures for different species of livestock, whereas, the middle-aged respondents $(n=6)$ mentioned that they provided the same mix of forage to all the livestock species. Families that differentiated between the livestock species prepared different feed mixtures for different animals with some differences as well as commonalities. Households that did not differentiate between the types of livestock species fed all livestock a mix of barley residue, green pea residue and forage collected from the agricultural fields, locally known as yursa, three times a day. An elderly respondent complained about the change in the region and their way of life: 'People are not willing to work hard towards ensuring that they are eating good food, how would they put hard work towards providing a proper diet to the livestock'.

The stall feed comprises a mix of grains, hay, fodder species collected from pastures and fodder species collected from in and around the agricultural fields. Main items that go into the stall feed have different local names. Chisa- a mixture of weeds collected from the agricultural areas; Sanfe and Pheed, powdered and roasted black pea; Chaak, a combination of powdered barley and Chang the local brew; Shimbuk and Phuma, the residue of green pea and barley respectively; and Neh and Chak which are different forms of barley (Table 2). Yaks are given Aconogonum molle, Cicer micophyllum and Cousinia thomsonii, which are also common in the cow and dzo diet. For horses, Allium wallichii and Cousinia thomsonii and, for goats and sheep, Heracleum spp., Geranium spp. and Festuca spp. are essential ingredients of the stall feed. Local elders also mentioned that species like $C$. thomsonnii have medicinal properties, and they give it to the livestock to treat and prevent foot-and-mouth disease.

The government also supplies livestock feed at highly subsidized rates in case of a drought or natural calamity. The herders pay only the transportation cost. In the last 5 years, agricultural residue from the neighbouring states of Himachal Pradesh, Haryana and Punjab has become an essential part of stall feed, while availability of imported fodder has emerged as a critical component in stabilizing the numbers of livestock. The imported fodder is easily available at shops in Kaza, the nearest town and district head office at 800 Indian rupees (c. 11 USD) for $50 \mathrm{~kg}$, which is an affordable price for the livestock herders in the study site.

Table 2 Locally prepared stall feed

\begin{tabular}{ll}
\hline Local name & Composition \\
\hline Chisa & A mixture of weeds from agricultural fields \\
Pheed & Powdered black pea \\
Chaak & Roasted black pea \\
& A combination of powdered barley and \\
Yursa & Chang, local brew \\
Piti Shanmanapo (sansa) & A mixture of grasses and plants found inside \\
& the agricultural field and on bunds. Black pea \\
Chinboo & With sedges \\
Shimbbuk & Green pea residue \\
Phuma & Barley residue \\
Maao & Locally known cumin plant grass \\
Neh, Chak & Barley in different forms
\end{tabular}

Local names and composition of the stall feed given to the livestock with different proportions of the mix based on availability with the herder 


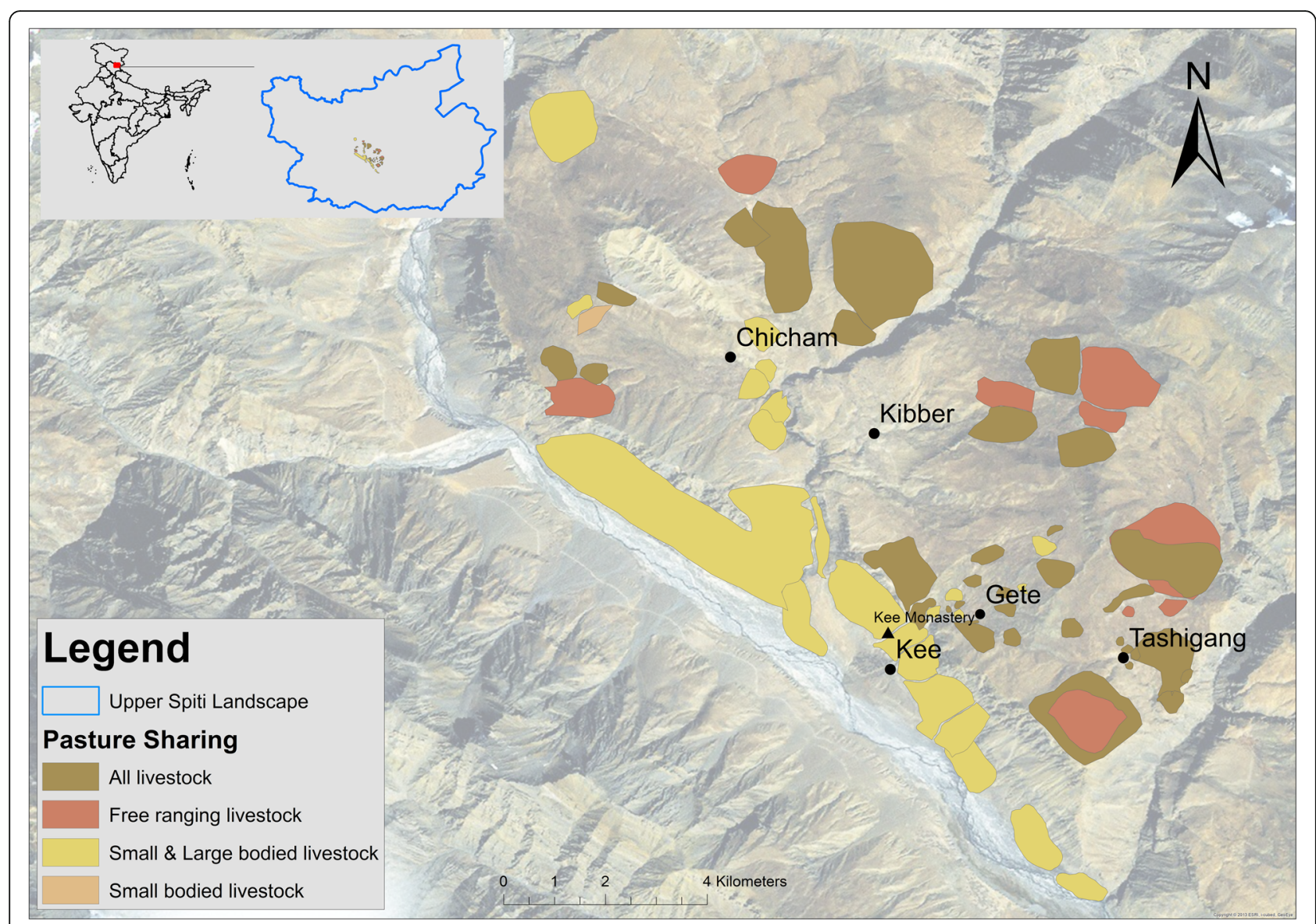

Fig. 1 Map showing pasture sharing between villages of the study area

\section{Local institutions and pasture sharing}

To fulfil the needs of diverse livestock types, herders of Spiti have developed a sophisticated system of livestock production that enables them to efficiently use rangelands. Local informal and formal institutions which play an essential role in resource sharing include the village council Panchayat; the elected/nominated village head, Goba; Animal Husbandry Department; Forest Department; and conservation NGOs working in the region. Linkages with the market continue to influence the local

\footnotetext{
${ }^{1}$ How and when these documents were made remains unclear even among the local elders. During one of the group discussions in Kibber, some of the respondents reported that the person they believe had done this partition was the grandfather of one of the kings of this place, Chuang Tubgye 300-400 years back. However, another set of respondents believed that the same person was ruling the area only 350 to 400 years back, and livestock rearing and pasture management in the area are as old as the human settlements in Spiti. Therefore, these people believe that the distribution of pastures must have been done by the elders themselves, without any interference by any of the ruling kings or state. Until 1846, Spiti was under the British India Company; for the next 2 years, the ruler was King of Bushahr, and in 1864, Tam-Zin Namgyal became the ruler (Bajpai, 2002); later, this place was under the rule of their local kings. It is possible that the documents regarding the pasture use were made during the King's time.
}

agricultural practices, which eventually have implications for livestock population and composition.

The local institutions' rules and regulations on pasture use in the region are in the form of a written document maintained by the Goba. Rules on pasture management in this document ensure appropriate management of pastures with minimal conflict. ${ }^{1}$ The document also contains a list of the villages with their assigned pastures. Altitudinal differences in assigned pastures compel villages to cooperate and share pastures to fulfil the seasonal needs of the diverse livestock herds. Traditionally, the villages maintained a hierarchical system comprising a chief herder, locally known as lugzi, and his assistants, who would take care of individual livestock species. This chief herder was an older adult with considerable knowledge of the bio-physical environment, seasonality and availability of fodder across the year. The village council/ panchayat assigned duties to different households to assist the chief herder.

Villages share pastures for both small-bodied livestock like goats and sheep and free-ranging animals like yaks and horses (Fig. 1). Herders make pasture selection decisions at two scales. They first select a large area for 


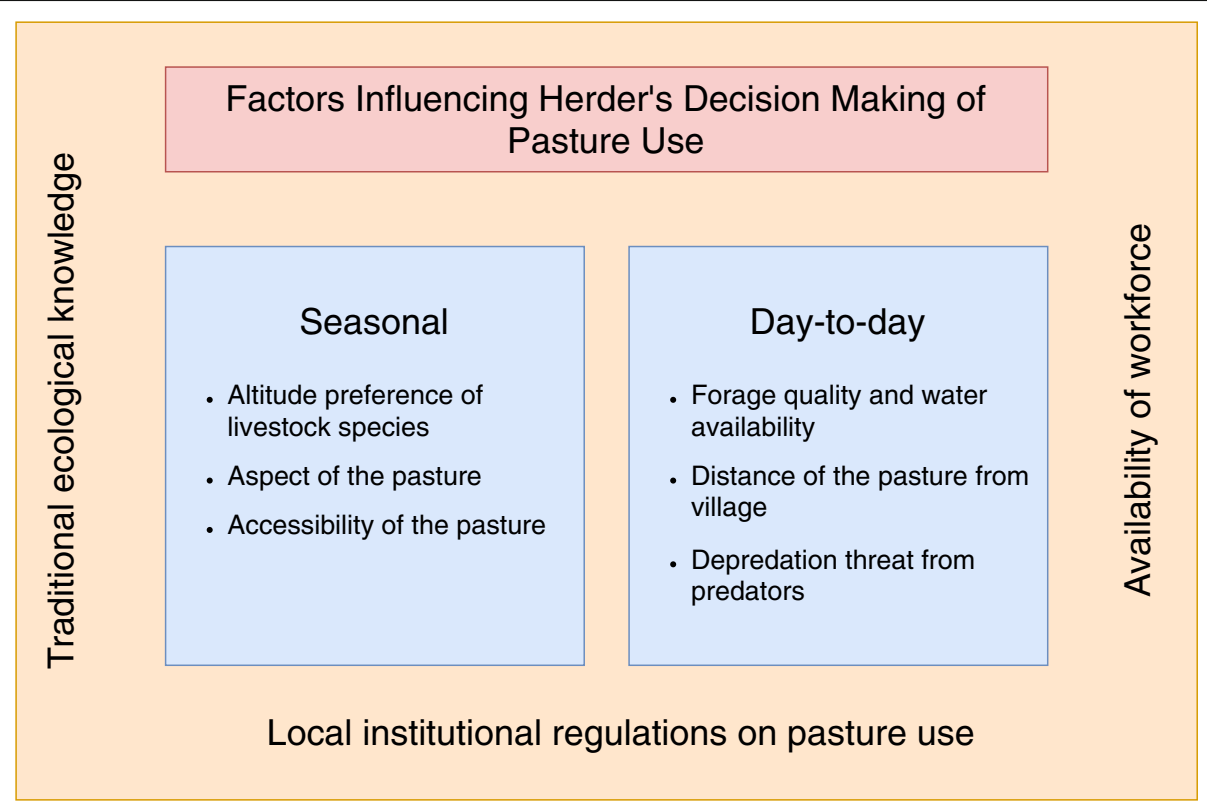

Fig. 2 Factors influencing decision-making for resource use: aspect, altitude and accessibility of the pasture on seasonal basis and distance from the villages, forage quality, water availability and threats from predators on daily basis were found to be important ecological factors influencing the decisions of herding practices. The ecological factors work in consonance with the social factors like availability of workforce and TEK of the herders and rules and regulations of local institutions regulate access and use of the pastures

seasonal use based on elevation and vegetation composition. Within this area, the herders use pastures rotationally on a day-to-day basis to avoid overgrazing and to avoid wild predators. Aspect, altitude preference of livestock type, timings of snowfall and snow melting were reported to be the main factors in determining seasonal pasture use. However, on a day-to-day basis, distance from the villages, forage quality based on the time of the year, water availability and threats from predators were the most critical factors (Fig. 2). These factors operate in the backdrop of workforce availability and TEK of the herders regarding the forage availability.

Aspect, altitude and accessibility were found to be important factors in decision-making for both ecological and practical reasons. The herders recognized the temporal and spatial variation between pastures and its influence on the availability of the fodder. Herders used high-elevation northern slopes for livestock (dzomo, sheep and goats, donkeys) in peak summer (July-Aug) while southern slopes, near villages, were used in spring and autumn (except for village Gete and Tashigang). The herders released yaks at mid-elevations (approx. $4000-4600 \mathrm{~m}$ ) in early summer from where they ascended to higher elevations with progressing summer (approx. 4600-5200 $\mathrm{m}$ and above). The yaks start descending to mid elevations (4000-4600) with the commencement of snowfall in early winters (November) and were herded back up to higher altitudes by mid-April, at the end of winter in the region. Yak herders, locally known as Yakziya, visit the pastures to provide salt and check on the body condition of yaks. Apart from elevation, aspect of the pastures also plays an essential role in yak rearing, since the snow melting, and fodder availability is influenced by aspect. For example, south-facing pastures of Chicham village and Kibber village are used by the yaks from April to June, since in most of these south-facing pastures, snow melts faster than other higher-altitude pastures. After June, north- and eastfacing pastures also undergo snowmelt and yaks are then sent to these pastures ${ }^{2}$. Timings for a particular pasture use can vary depending upon the timings of snowfall and snowmelt. Neighbouring villages shared pastures with good quality fodder for small-bodied livestock. ${ }^{3}$

Village Gete has a large area of high quality, rolling pastures. There are only seven households in this village, but it plays a vital role in livestock management of Kibber panchayat. Several households from other villages of the panchayat, who are engaged in government jobs or do not have sufficient family members to take care of

\footnotetext{
${ }^{2}$ Some of the important north- and east-facing pastures are Thinnam, Ar, Minkyut, Chirsala and Chugyesa. Yaks belonging to villages at relatively lower altitude like Khurik, Sumling and Pangmo are brought to Kibber (4200) and Chicham (4000) due to their relatively higher altitude pastures. Pastures of Kibber and Chicham are considered best suited for yaks because of their forage quality and altitude preference of yaks.

${ }^{3}$ Pastures are shared between Kibber and Chicham and Gete and Tashigang for small- and large-bodied animals as these villages are situated closest to each other.
} 
livestock around the year, leave their livestock in Gete during the summer season (April to September). Herders in charge of animals charge a herding fee for a summer season at 300 rupees (4 USD) for every medium-bodied livestock like cow or dzomo and $150 \mathrm{ru}$ pees ( 2 USD) for small-bodied livestock like goats and sheep. The pastures of Gete provide sustenance during summers for their livestock. In winters, Gete becomes inaccessible by road; therefore, before the beginning of snowfall, members of Gete village move back to their alternative house (in Kee and Kaza) and stall-feed their animals. Owners of the livestock herds from other villages also bring their animals back to their village and stall-feed them during winters.

\section{Changes in livestock production and traditional ecological knowledge}

In the last 5 to 7 years, local peoplein the study area have started cultivating wheat to meet the fodder requirement for stall feeding. Changes in the crops and cultivation patterns have continued to influence the livestock species composition and numbers in the region. Three decades ago, an experiment of cultivating green peas as a cash crop succeeded and became the dominant crop in the villages of the study area. This crop has replaced black pea and barley, the traditional crops in the region that carried cultural significance and were also crucial for livestock production. In the years 2010-2012, reduced snowfall and a concomitant decline in the biomass of green pea was one among other social and ecological reasons for the $50 \%$ decline in livestock numbers between year 2003-2011 (Fig. 3). The availability of fodder for stall feeding during long winters when resources are scarce has been a critical determinant of livestock holding. The recent shift to wheat cultivation, primarily for its hay for stall feed, as well as fodder bought by the Animal Husbandry Department from the neighbouring states of Haryana and Punjab, is resulting in increasing livestock numbers (Fig. 3). The total number of livestock has increased by $26.45 \%$ between year 2011-2016 where the maximum increase has been in the number of yaks and demo with $95.58 \%$ increase followed by dzomo with $30.83 \%$ increase. The number of sheep and donkeys have remained comparable over the same period, but there is a threefold increase in horse numbers. People in Kee, Gete and Teshigang have stopped keeping goats. In addition to this, the availability of immigrant labourers for herding livestock has added to the ability of local herders to maintain higher livestock numbers.

Key informants reported a shortage of experienced herders having knowledge of livestock needs and pasture quality around the year. They attributed this

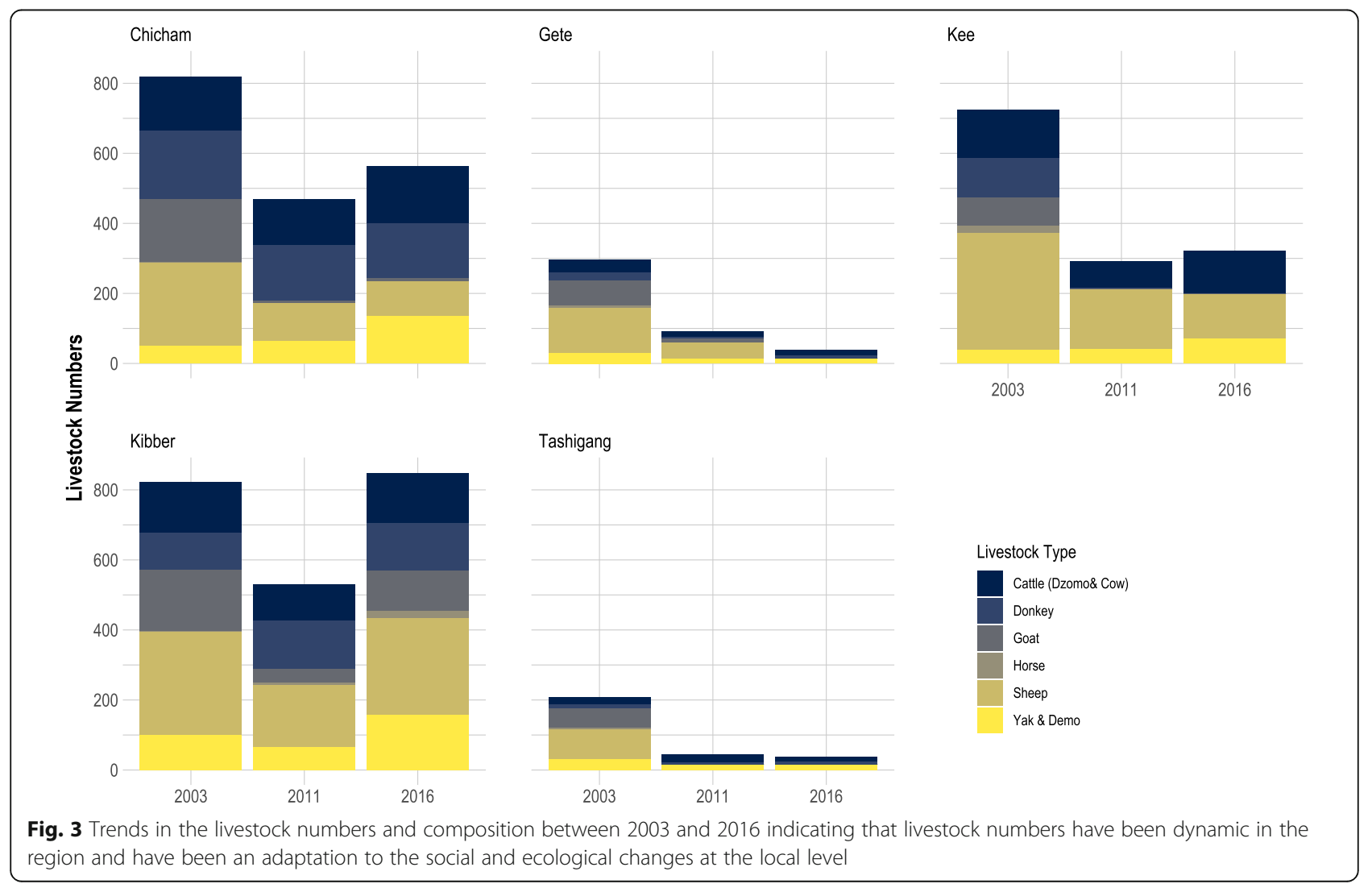


shortage to the loss of TEK in the pastoral community, primarily due to lack of knowledge transmission between generations and also to the demographic changes in the region. The loss of TEK was a result of several interconnected events in recent history. First, increased income from cash crops shifted the primary source of income from livestock production to crop farming. Local people invested a higher amount of their time and energy in the cultivation of cash crops. Second, with better income from cash crops, local communities could afford education for their children in private and boarding schools. The young generation hence gets very little time and exposure to the TEK associated with livestock management and resource use. The young generation is also seeking other lucrative and secure livelihood options such as government jobs, cash crops, cultivation and activities associated with tourism. The shift in priorities and aspirations leads to a shortage of workforce for livestock herding at the household level. The most critical reason for the change in the pastoral social-ecological systems and loss of TEK is the arrival of immigrant labour as an important actor in livestock rearing. The immigrant labour has increasingly filled the workforce gap required for herding but with a diminished knowledge of the traditional resource management system.

The local communities in Spiti have hired labourers from the plains of India and Nepal for livestock herding over the past decade. During the last documented government census, the population of immigrants in Upper Spiti was reported to be 853 , out of which 322 were from Indian plains and 531 from Nepal (Anon 2011). These labourers were earlier engaged in contractual construction work and household chores but are increasingly taking on the role of livestock herding. The experienced local elders brief the labourers about the directions and pastures they are supposed to take the livestock, daily.

Respondents mentioned that these labourers lack the skills of a herder and also do not understand the need and rationale behind the rotational use of pasture. During our survey, respondents $(n=6)$ mentioned that instead of taking livestock to the pasture designated by the main herders, labourers are often seen grazing livestock in other nearby pastures. These labourers are also reported not to care much for livestock needs as noted in one response:

Immigrant labourers go out with the livestock, but they treat this as a job and do not take care of the livestock and whether or not they have eaten well. (33-year-old female respondent, Kibber village)

With the loss of knowledge about rangelands and stochasticity of environmental factors such as water and resource availability, the current generation of local herders is finding it difficult to deal with increasing extreme climatic events. For example, in the winter of 2018-2019, one of the young herders from Kibber village used social media to look for a knowledgeable herder who could take care of his herd for a season. Failing to find one after a month, he posted again, asking for places to graze his livestock in the event of a high snowfall.

\section{Discussion}

\section{Application of TEK in livestock management}

Our results show that the local herders have a rich understanding of the fodder requirements of their livestock species based on their body size and physiology. The herders incorporate this knowledge of forage preferences and the role of seasonality in pastures to maximize the resource use of rangelands by a diverse set of livestock. In terms of respondents' reports of the altitudinal preference of livestock species, our findings share similarities with an earlier ecological study in the region which addressed the issues of competition between wild ungulates and local livestock (Bagchi, Mishra, and Bhatnagar 2004) and other similar high-altitude pastoral systems of Bhutan and Nepal (Aryal, Maraseni, and Cockfield 2014; Namgay et al. 2013).

The experienced herders believed that considering requirements of animals is essential to keeping them healthy. Several studies have highlighted an understanding of livestock nutrient requirements and fodder species preferences of different livestock as an important part of TEK about livestock diet in high-altitude pastoral systems across Spain, Colorado and highlands of Mongolia (Fernandez-Gimenez 2000; Fernandez-Gimenez and Estaque 2012; Knapp and Fernandes-Gimenez 2009). Stall feed prepared by older herders of the study area depicted a rationale of maintaining the feed nutrient value across different seasons. For example, herders give mustard oil to yaks with the stall feed during the crop agricultural season, but that is not what a goat and sheep would need. The herders believe mustard oil provides energy to yaks while working in the agricultural fields. Different combinations of ingredients are used to prepare stall feed as a balanced diet. For example, the agricultural residue of barley, Aconogonum molle and Festuca spp. provides sufficient biomass, but since the residue is dry and low in nutrition, herders mix it with green pea stalk and leaves for balancing moisture and nutrients' content of the stall feed. We can attribute the age-based difference in herders' knowledge about quality of livestock feed preparation to socio-economic changes in the region and lack of opportunities for the younger generation to gain the traditional knowledge. 
We can consider this study as a first attempt to document TEK related to livestock production systems by the herders of Spiti Valley. Our in-depth interviews provided a window into the vast pastoral knowledge on rangeland management, important fodder species and livestock diet preferences. We propose that intensive indepth research is needed to document the wide range of knowledge that the herders possess regarding the spatial occurrence of fodder species; changes in their abundance and distribution, and impacts of climate change on pastoralism and rangelands. Our study included only male herders, and including women's knowledge of animal care would add additional new perspectives on livestock management.

\section{Spatial and temporal use of pastures}

Herders use pasture rotationally with seasonal and daily variations depicting adaptations to topographic, ecological and climatic factors. Rotational use of pastures in the study area is also a common practice in parts of Africa and Asia (Brottem et al. 2014; FernandezGimenez 2000; Behnke et al. 2011; Butt 2010; Turner, McPeak, and Ayantunde 2014; Aryal, Cockfield, and Maraseni 2018; Namgay et al. 2013; Niamir-Fuller et al. 2012), where multiple seasonal factors such as variability of rainfall, precipitation trends and seasonal vegetation patterns influence the decisions of pasture use.

We found accessibility, altitude and aspect to be the most important factors in decision-making about pasture use. Herders reserved pastures closer to the village for the winters, as winter snow makes it difficult for livestock and the accompanying herders to access the distant pastures. Also, the level of water in the river streams (if there is a stream between the village and the pasture) plays an important role in pasture access and its selection. We found that aspect and slope of the pastures were crucial factors in decision-making on pasture use, which is in agreement with the role of terrain in pastoral decision-making in Spanish highlands (Fernandez-Gimenez and Estaque 2012). Southern, and especially the lower, slopes are much more accessible and suitable for livestock grazing as they become snow-free more often and are relatively warmer.

Earlier studies done in eastern and western parts of Africa show that pasture use by the local communities is an adaptation to seasonal variation in forage availability (Butt 2010; Brottem et al. 2014), which emerged as a key finding of our study. We observed that herders used different pastures in different seasons, depending upon the forage availability during those different seasons. Another study from Mongolia on the role of TEK showed that pasture management is embedded in the classification of pasture resources, where quality and quantity of both water and forage are critical (Fernandez-Gimenez
2000); these are factors that herders in our study also reported to be important in decision-making.

\section{Demographic and agricultural change and ramification for rangelands}

In Spiti, a number of factors are influencing the social, cultural and ecological dimensions of the agro-pastoral systems: changing aspirations; availability of lucrative job options like cash crop cultivation and tourism; arrival of immigrant labourers as new actors in the livestock management; and cultivation of wheat and availability of commercial livestock feed from the market. Studies on pastoral system in the high-altitude regions of Asian countries like Nepal, Mongolia and Tibet have reported that while immigration of seasonal labour and outmigration of local community members has influenced the local economy positively, there were negative impacts on the social and cultural aspects of the community (Aryal, Cockfield, and Maraseni 2018; Gentle and Thwaites 2016; Kreutzmann 2012; Namgay et al. 2013). Spiti, being a coupled social-ecological system too, changes in the social component of the system (demographic change) may influence the ecological component (rangelands and wildlife) in the long run.

Stall feed and workforce at the household level have been the limiting factors for the herd size in the past, but with the recent availability for stall feed from the market and manpower in the form of immigrant labourers, the local communities can afford to increase their livestock herd size. We speculate that an increase in the livestock numbers in the future and continuation of migrant labourers as livestock caretakers may have negative impacts on local livestock production, health of rangelands and the wildlife. The immigrant labourers do not have the skills required for livestock management, and they do not understand the significance of pasture rotation for the health of rangelands and the livestock. In the absence of TEK, migrant labourers playing the role of herders overstock pastures closer to villages. In the long run, this could lead to degradation of rangelands and may also influence the reproductive health of livestock in the absence of a proper diet. Increased livestock numbers may also have implications for wildlife conservation in the region by negatively affecting the wild ungulate and carnivore populations. In the past, overstocking of these rangelands was seen to result in resource competition between livestock and wild ungulates (Bhatnagar et al. 2006; Bagchi and Ritchie 2010a). A recent study has also pointed out the thresholds of livestock stocking densities, beyond which increasing livestock populations negatively influences snow leopards and wild ungulates (Sharma, Bhatnagar, and Mishra 2015). 
TEK has helped the herders to cope with natural shocks and long-term changes in nature and society across high-altitude regions of Asia and Africa (Jandreau and Berkes 2016; Conte and Tilt 2014; Brower 1990; Sheehy, Miller, and Johnson 2006; Kreutzmann 2012). However, we observed a clear loss of transmission of this knowledge to younger generations and the immigrant labourer force in Spiti Valley. With changing aspirations and opportunities for higher education away from villages, local young people are increasingly moving to towns for higher education; as a consequence they have reduced exposure to the local livestock management and associated knowledge of their bio-physical environment. Influence of development and modernity on Masai herders shows similar outcomes, where shrinking spaces for learning and exchange of folk knowledge between generations is resulting in a process of 'acculturation', obstructing knowledge flow over generations (Jandreau and Berkes 2016). We found that the middle-aged herders too were not aware of fodder species names that they see in the pastures and agricultural fields, which again signifies erosion of TEK in pursuit of new opportunities against a backdrop of ongoing socio-economic changes. Studies in parts of South America and Europe report similar erosion trends of traditional knowledge (Reyes-García et al. 2005; Gomez-Baggethun et al. 2010). Decline in the availability of such knowledge holders is a cause of concern, not only because of its effects on the current livestock herding and pasture management system, but also because of long-term impacts on the continuity of sharing knowledge across generations.

\section{Conclusion}

Pastoral landscapes like Spiti are prone to unpredictable events such as extreme snow fall and poor precipitation for consecutive years. This study highlights the role of TEK in livestock management and sustainable resource use. TEK about the local environment and resource availability has been crucial in sustaining the pastoral social-ecological systems in Spiti Valley. Experienced elder herders have the ethno-botanical knowledge of the palatable species which ensures adequate nutritional care of a variety of livestock species. They also possess knowledge of critical spaces that can help in periods of lower precipitation and extreme snowfall; as well as knowledge about medicinal properties of some fodder species for treating animals with minor illnesses. However, with the socio-economic and demographic changes at the local and regional level, together with changing aspirations of the younger generation, the TEK seems to be on the decline in terms of application to the current livestock herding practices and knowledge transmission to younger generations. The current trajectory of change in the livestock management practices, loss of TEK, increasing numbers of livestock and inclusion of non-traditional grazing practices by migrant labourers, can all lead to grazing intensification in some pastures, thus compromising both livestock production and wildlife conservation. Socio-economic changes in the Himalayan region have been mainly examined in order to understand their influence of these changes on livestock production and livestock management. This study highlights the role of TEK in these high-altitude pastoral systems and examines how socio-economic and demographic changes in the region are influencing the knowledge system which is critical for the sustenance of these systems. We propose that responses of pastoral systems to the social and ecological stressors should be examined at regular intervals for a deeper understanding of emerging pastoral trends and the ramifications for pastoralism and conservation.

\section{Acknowledgements}

Himachal Pradesh Forest Department and Animal Husbandry Department, Kaza, are thanked for their support and cooperation. We sincerely thank Sumanta Bagchi for sharing his extensive knowledge and helping in identification of the fodder species. We thank Kesang Chunit, Tenzin Thuktan, Rinchen Tobge, Tandup Chhering and Sherap for their wholehearted support during the study. A special thanks to Tanzin Thinley for sharing his knowledge and being a generous host. People of Kibber and all the respondents are thanked for sharing their valuable knowledge.

The lead author thanks Asmita Kabra at the School of Human Ecology, Ambedkar University Delhi, for providing her valuable guidance during the study. Rohit Negi at the School of Global Affairs, Ambedkar University Delhi, is thanked for being extremely generous and providing his valuable insights on multiple occasions. Discussions with Rohan D'Souza and Shinya Takeda at Graduate School of Asian and African Area Studies (ASAFAS), Kyoto University, were immensely useful in improving the paper. Shiwani Yadav at the Centre for Urban Ecology and Sustainability, Ambedkar University Delhi, is thanked for helping with the map. Ratika Kathuria is thanked for her help in data curation. Ajay Immanuel Gonji, Divya Upadhyay, Meenakshi Singh, Shashank Bhardwaj and Syed Shoaib Ali are thanked for their constant support.

\section{Authors' contributions}

RS carried out the fieldwork, analysed the data and wrote the manuscript. RKS contributed to the study design, data collection, data analysis and writing of the manuscript. SB contributed to the study design, data analysis and structuring of the manuscript. YVB conceived the study and provided overall guidance on the data collection, analysis and drafting of the manuscript. All authors edited and approved the final manuscript.

\section{Authors' information}

Rashmi Singh is a Doctoral Candidate at the School of Human Ecology, Ambedkar University Delhi. Miss Singh has been studying the pastoral communities of the Indian Himalaya for her Master's and PhD research. She is interested in understanding issues at the interface of human-nature entanglements using mixed methods and ethnographic approaches using interdisciplinary framework.

\section{Funding}

Nature Conservation Foundation provided financial support for the first round of data collection. The second round of the data collection was selffunded by the lead author.

Availability of data and materials

The datasets used for the current study are available from the corresponding author on reasonable request. 


\section{Ethics approval and consent to participate}

We have conducted this study adhering to the national and international standards governing research of this nature.

\section{Consent for publication}

Not applicable.

\section{Competing interests}

Declaration: The authors declare that they have no competing interests.

\section{Author details}

'School of Human Ecology, Ambedkar University Delhi, New Delhi 110006, India. ${ }^{2}$ Worldwide Fund for Nature-India, Lodhi Estate, New Delhi 110003, India. ${ }^{3}$ Nature Conservation Foundation, Vijayanagar, Mysuru, Karnataka 570017, India.

Received: 7 September 2019 Accepted: 23 April 2020

Published online: 17 July 2020

\section{References}

Adriansen, Hanne Kristine. 2008. Understanding pastoral mobility: The case of Senegalese Fulani. The Geographical Journal 174 (3): 207-222 https://doi.org/ 10.1111/j.1475-4959.2008.00278.x.

Ahmed, Mossa Endris, and Bihi Mohammed Ahmed. 2019. Indigenous knowledge for resilience and adaptation in pastoral production system of Somali Regional State in Ethiopia. Interdisciplinary Description of Complex Systems 17 (4): 723-737.

Anon. 2011. Management Plan for the Upper Spiti Landscape Including the Kibber Wildlife Sanctuary. Himachal Pradesh: Wildlife Wing, Himachal Pradesh Forest Department. https://doi.org/10.13140/RG.2.2.23390.64324.

Aryal, Suman, Geoff Cockfield, and Tek Narayan Maraseni. 2018. Globalisation and traditional social-ecological systems: Understanding impacts of tourism and labour migration to the transhumance systems in the Himalayas. Environmental Development 25: 73-84 https://doi.org/10.1016/j.envdev.2017. 09.001 .

Aryal, Suman, Tek Narayan Maraseni, and Geoff Cockfield. 2014. Sustainability of transhumance grazing systems under socio-economic threats in Langtang, Nepal. Journal of Mountain Science 11 (4): 1023-1034 https://doi.org/10.1007/ s11629-013-2684-7.

Bagchi, Sumanta, Charudutt Mishra, and Y.V.V. Bhatnagar. 2004. Conflicts between traditional pastoralism and conservation of Himalayan ibex (Capra sibirica) in the Trans Himalayan Mountains. Animal Conservation 7: 121-128 https://doi. org/10.1017/S1367943003001148.

Bagchi, Sumanta, and Mark E Ritchie. 2010a. Body size and species coexistence in consumer-resource interactions: A comparison of two alternative theoretical frameworks. https://doi.org/10.1007/s12080-010-0105-x.

Bagchi, Sumanta, and Mark E. Ritchie. 2010b. Introduced grazers can restrict potential soil carbon sequestration through impacts on plant community composition. Ecology Letters 13 (8): 959-968 https://doi.org/10.1111/j.14610248.2010.01486.x.

Behnke, R.H., M.E. Fernandez-Gimenez, Matthew D. Turner, and F. Stammler. 2011. Pastoral migration: Mobile systems of animal husbandry. In Animal migration: A synthesis, ed. E.J. Miller-Gulland, J.M. Fryxell, and A.R.E. Sinclair, 144-171. Oxford: Oxford University Press.

Beinart, W. 1996. Environment destruction in southern Africa. In The lie of the land: Challenging received wisdom on the African environment, ed. M. Leach and R. Mearns, 54-72. Oxford: James Curry.

Berkes, Fikret. 2004. Rethinking community based conservation. Conservation Biology 18 (3): 621-630.

Berkes, Fikret. 2008. Sacred ecology. Second. New York: Routledge.

Berkes, Fikret, and Carl Folke, eds. 1998. Social and ecological systems: Management practices and social mechanism for building resilience. Cambridge: Cambridge University Press.

Bhasin, Veena. 2011. Pastoralists of Himalayas. Journal of Human Ecology 33 (3): 147-177.

Bhasin, Veena. 2012. Social organization, continuity and change: The case of the Bhutias of Lachen and Lachung of North Sikkim. Journal of Biodiversity 3 (1): 1-43.

Bhatnagar, Yash Veer, Rinchen Wangchuk, Herbert H.T. Prins, Sipke E. Van Wieren, and Charudutt Mishra. 2006. Perceived conflicts between pastoralism and conservation of the Kiang Equus kiang in the Ladakh Trans-Himalaya, India.
Environmental Management 38 (6): 934-941 https://doi.org/10.1007/s00267005-0356-2.

Brottem, Leif, Matthew D. Turner, Bilal Butt, and Aditya Singh. 2014. Biophysical variability and pastoral rights to resources: West African transhumance revisited. Human Ecology 42 (3): 351-365 https://doi.org/10.1007/s10745-0149640-1.

Brower, Barbara. 1990. Range conservation and Sherpa livestock management in Khumbu, Nepal. Mountain Research and Development 10 (1): 34-42.

Butt, B. 2010. Pastoral resource access and utilization: Quantifying the spatial and temporal relationships between livestock mobility, density and biomass availability in southern Kenya. Land Degradation \& Development 21 (6): 520 539 https://doi.org/10.1002/ldr.989

Butt, Bilal. 2011. Coping with uncertainty and variability: The influence of protected areas on pastoral herding strategies in East Africa. Human Ecology 39: 289-307 https://doi.org/10.1007/s10745-011-9399-6.

Chapin, F.S., G.P. Kofinas, C. Folke, and M.C. Chapin. 2009. Principles of ecosystem stewardship resilience-based natural resource management in a changing world. New York: Springer

Conte, Thomas J., and Bryan Tilt. 2014. The effects of China's grassland contract policy on pastoralists' attitudes towards cooperation in an Inner Mongolian Banner. Human Ecology 42 (6): 837-846 https://doi.org/10.1007/s10745-0149690-4.

Davis, D.K. 2005. Indigenous knowledge and the desertification debate: Problematising expert knowledge in North Africa. Geoform 36: 509-524.

Denizen, N., and Y. Lincoln. 2017. Handbook of qualitative research. Thousand Oak: Sage.

Dregne, H.E., M. Kassa, and B. Rosanov. 1991. A new assessment of the world status of desertification. Desertification Control Bulletin 20: 6-18.

Ferguson, Michael A.D., Robert G. Williamson, and François Messier. 1998. Inuit knowledge of long-term changes in a populaion of Arctic Tundra Caribou. Arctic 51 (3): 201-219.

Fernandez-Gimenez, M.E., and Federico Fillat Estaque. 2012. Pyrenean patoralists' ecological knowledge: Documentation and application to natural resource management and adaptation. Human Ecology 40: 287-300.

Fernandez-gimenez, Maria E. 2000. The role of Mongolian nomadic pastoralists ' ecological knowledge in rangeland management. Ecological Applications 10 (5): 1318-1326

Galvin, K. 2009. Transitions: Pastoralists living with change. Annual Review of Anthropology 38: 185-198.

Gentle, Popular, and Rik Thwaites. 2016. Transhumant pastoralism in the context of socioeconomic and climate change in the mountains of Nepal. Mountain Research and Development 36 (2): 173-182 https://doi.org/10.1659/mrdjournal-d-15-00011.1.

Ghoshal, A. 2017. Determinants of occurrence of snow leopards and its prey species in the Indian Greater and Trans Himalaya. Rajkot: Wildlife Science department, Saurashtra University.

Goldstein, M.C., and C.M. Beall. 1990. Nomads of Western Tibet: The survival of a way of life. Berkeley: University of California Press.

Gomez-Baggethun, E., S. Mingorria, Reyes-garcía Victoria, L. Calvet, and C. Montes. 2010. Traditional ecological knowledge trends in the transition to a market economy: Emperical study in Donana natural area. Conservation Biology 24: 721-729.

Gómez-Baggethun, Erik, Esteve Corbera, and Victoria Reyes-García. 2013. Traditional ecological knowledge and global environmental change: Research findings and policy implications. Ecology and Society 18 (4) https:// doi.org/10.5751/ES-06288-180472.

Gómez-baggethun, Erik, and Victoria Reyes-garcía. 2013. Reinterpreting change in traditional ecological knowledge. Human Ecology 41: 643-647 https://doi. org/10.1007/s10745-013-9577-9.

Gunderson, L.H., and C.S. Holling. 2002. Panarchy: Understanding transformation in human and natural systems. Washington DC: Island Press, Washington.

Hardin, Garrett. 2009. The tragedy of the commons. Journal of Natural Resource Policy Research 1 (3): 243-253 https://doi.org/10.1080/19390450903037302.

Harris, R.B. 2010. Rangeland degradation on the Qinghai-Tibetan plateau: A review of the evidence of its magnitude and causes. Journal of Arid Environments 74 (1): 1-12 https://doi.org/10.1016/j.jaridenv.2009.06.014.

Ho, Peter. 2000. China's rangelands under stress : A comparative study of pasture commons in the Ningxia Hui Autonomous Region. Development and Change 131 (2): 385-412.

Jandreau, Connor, and Fikret Berkes. 2016. Continuty and change within the social-ecological and political landscape of the Maasai Mara, Kenya. Pastoralism: Research, Policy and Practice 6 (1): 1-15. 
Johnson, Douglas A., Dennis P. Sheehy, Daniel Miller, and Daalkhaijav Damiran. 2006. Mongolian rangelands in transition. Scheresse 17 (1-2): 133-141.

Kakinuma, Kaoru, Tomoo Okayasu, Takehiro Sasaki, Undarmaa Jamsaran, Toshiya Okuro, and Kazuhiko Takeuchi. 2013. Rangeland management in highly variable environments: Resource variations across the landscape mediate the impact of grazing on vegetation in Mongolia. Grassland Science 59 (1): 44-51 https://doi.org/10.1111/grs.12008.

Kreutzmann, Hermann, ed. 2012. Pastoral practices in High Asia. Advances in Asian human-environmental research. Dordrecht: Springer Netherlands https://doi. org/10.1007/978-94-007-3846-1.

LeCompte, M., and J. Schensul. 1999. Analyzing and interpreting ethnographic data. Walnut Creek: Altamira Press.

Li, Wen Jun, Saleem H. Ali, and Qian Zhang. 2007. Property rights and grassland degradation: A study of the Xilingol pasture, Inner Mongolia, China. Journal of Environmental Management 85 (2): 461-470 https://doi.org/10.1016/j. jenvman.2006.10.010.

Li, Wenjun, and Yanbo Li. 2012. Managing rangeland as a complex system: How government interventions decouple social systems from ecological systems. Ecology and Society 17 (1) https://doi.org/10.5751/ES-04531-170109.

Mallory, Mark L., H. Grant Gilchrist, Alain J. Fontaine, and Jason A. Akearok. 2003. Local ecological knowledge of Ivory Gull declines in Arctic Canada. Arctic 56 (3): 293-298.

Mapinduzi, Arnold L., Gufu Oba, Robert B. Weladji, and Jonathan E. Colman. 2003. Use of indigenous ecological knowledge of the Maasai pastoralists for assessing rangeland biodiversity in Tanzania. African Journal of Ecology 41 (4): 329-336 https://doi.org/10.1111/j.1365-2028.2003.00479.x.

McMillen, H., T. Ticktin, and K.S. Hannah. 2017. The future is behind us: Traditional ecological knowledge and resilience over time on Hawai'i Island. Regional Environmental Change 17: 579-592.

Mishra, Charudutt. 2000. Socioeconomic transition and wildlife conservation in the Indian Trans-Himalaya. Bombay Natural History Society 97 (1): 25-32.

Mishra, Charudutt. 2001. High altitude survival: Conflicts between pastoralism and wildlife in the Trans-Himalaya. The Netherlands: Wageningen University.

Mishra, Charudutt, Herbert H.T. Prins, and S.E. Van Wieren. 2001. Overstocking in the trans-Himalayan rangelands of India. Environmental Conservation 28 (3): 279-283.

Mishra, Charudutt, Herbert H.T. Prins, and S.E. Van Wieren. 2003. Diversity, risk mediation, and change in a Trans-Himalayan agropastoral system. Human Ecology 31 (4): 595-609 https://doi.org/10.1023/B:HUEC.0000005515.91576.8f.

Mishra, Charudutt, Sipke E. Van Wieren, PieterHeitkönig Ketner, M.A. Ignas, and Herbert H.T. Prins. 2004. Competition between domestic livestock and wild Bharal Pseudois Nayaur in the Indian Trans-Himalaya. Journal of Applied Ecology 41: 344-354.

Mortimore, M., and B. Turner. 2005. Does the Sahelian smallholder's management of woodland, farm trees, rangeland support the hypothesis of humaninduced desertification? Journal of Arid Environments 63 (3): 567-595.

Mortimore, Michael. 1998. Roots in the African dust: Sustaining the sub-Saharan drylands. Cambridge: Cambridge University Press.

Nakashima, D.J. 1991. The ecological knowledge of Belcher Island Inuit: A traditional basis for contemporary wildlife co-management. Montreal: McGill University.

Namgail, Tsewang, Yash Veer Bhatnagar, Charudutt Mishra, and Sumanta Bagchi. 2007. Pastoral nomads of the Indian Changthang: Production system, landuse and socioeconomic changes. Human Ecology 35 (4): 497-504. https://doi.org/10.1007/s10745-006-9107-0.

Namgay, Kuenga, Joanne Millar, Rosemary Black, and Tashi Samdup. 2013. Transhumant agro-pastoralism in Bhutan: Exploring contemporary practices and socio-cultural traditions. Pastoralism: Research, Policy and Practice 3 (1): 13 https://doi.org/10.1186/2041-7136-3-13.

Namgay, Kuenga, Joanne E. Millar, Rosemary S. Black, and Tashi Samdup. 2014. Changes in transhumant agro-pastoralism in Bhutan: A disappearing livelihood? Human Ecology 42 (5): 779-792 https://doi.org/10.1007/s10745014-9684-2.

Niamir-Fuller, Maryam, Carol Kerven, Robin Reid, and Eleanor Milner-Gulland. 2012. Co-existence of wildlife and pastoralism on extensive rangelands: Competition or compatibility? Pastoralism: Research, Policy and Practice 2 (1): 8 https://doi.org/10.1186/2041-7136-2-8.

Ostrom, Elinor. 1990. Governning the commons: The evolution of institutions for collective action. Cambridge: Cambridge University Press.

Paltsyn, M. Yu, J.P. Gibbs, and G. Mountrakis. 2019. Integrating traditional ecological knowledge and remote sensing for monitoring rangeland dynamics in the Altai Mountain Region. Environmental Management 64: 40-51.
Reid, Robin S., María E. Fernández-Giménez, and Kathleen A. Galvin. 2014. Dynamics and resilience of rangelands and pastoral peoples around the globe. Annual Review of Environment and Resources 39 (1): 217-242 https:// doi.org/10.1146/annurev-environ-020713-163329.

Reyes-garcía, Victoria, V. Vadez, E. Bryron, L. Apaza, W.R. Leonard, E. Perez, and D. Wilkie. 2005. Market economy and loss of folk knowledge of plant uses: Estimates from Tsimane of Bolvin Amazon. Current Anthropology 46: 651-656.

Scoones, lan. 1994. Living with uncertainty: New directions in pastoral development in Africa. London: Intermidiate technology publications.

Sharma, Rishi Kumar, Yash Veer Bhatnagar, and Charudutt Mishra. 2015. Does livestock benefit or harm snow leopards? Biological Conservation 190: 8-13 https://doi.org/10.1016/j.biocon.2015.04.026.

Sheehy, D.P., D. Miller, and D.A. Johnson. 2006. Transformation of traditional pastoral livestock systems on the Tibetan steppe. Science et Changements Planétaires/Sécheresse 17 (1): 142-151.

Singh, Navinder J., Yash Veer Bhatnagar, Nicolas Lecomte, Joseph L. Fox, and Nigel G. Yoccoz. 2013. No longer tracking greenery in high altitudes: Pastoral practices of Rupshu nomads and their implications for biodiversity conservation. Pastoralism: Research, Policy and Practice 3 (1): 1 https://doi.org/ 10.1186/2041-7136-3-16.

Singh, Rashmi. 2013. Pasture management and the role of traditional institutions in long-term sustenance of high altitude pastures, Spiti, Himachal Pradesh. Delhi: Ambedkar University.

Singh, Rashmi, Rishi Kumar Sharma, and Suresh Babu. 2015. Pastoralism in transition: Livestock abundance and herd composition in Spiti, TransHimalaya. Human Ecology 43 (6): 799-810 https://doi.org/10.1007/s10745015-9789-2.

Soma, Takuya, and Schlecht. 2018. The relevance of herders' local ecological knowledge on coping with livestock losses during harsh winters in Western Mongolia. Pastoralism: Research, Policy and Practice 8 (3): 1-14.

Thapa, Sunita, John All, and Ram Kailash Prasad Yadav. 2016. Effects of livestock grazing in pastures in the Manaslu Conservation Area, Nepalese Himalaya. Mountain Research and Development 36 (3): 311 https://doi.org/10.1659/mrdjournal-d-13-00066.1.

Turner, Matthew D., John G. McPeak, and Augustine Ayantunde. 2014. The role of livestock mobility in the livelihood strategies of rural peoples in semi-arid West Africa. Human Ecology 42 (2): 231-247 https://doi.org/10.1007/s10745013-9636-2.

Turner, Nancy J., Marianne Boelscher Ignace, and Ronald Ignace. 2000. Traditional ecological knowledge and wisdom of aboriginal peoples in British Columbia. Ecological Applications 10 (5): 1275-1287.

Wang, Yun, and Karsten Wesche. 2016. Vegetation and soil responses to livestock grazing in Central Asian grasslands: A review of Chinese literature. Biodiversity and Conservation 25 (12): 2401-2420 https://doi.org/10.1007/s10531-015-1034-1.

Wyllie de Echeverria, V.R., and T.F. Thornton. 2019. Using traditional ecological knowledge to understand and adapt to climate and biodiversity change on the Pacific Coast of North America. Ambio 48: 1447-1469.

Yamaguchi, T. 2011. Transition in mountain pastoralism: An agro diversity analysis of the livestock population and herding strategies in Southwest Tibet, China. Human Ecology 39 (2): 141-154.

\section{Publisher's Note}

Springer Nature remains neutral with regard to jurisdictional claims in published maps and institutional affiliations. 